\title{
Identification of genetic variants in pharmacogenetic genes associated with type 2 diabetes in a Mexican-Mestizo population
}

\author{
NIDIA SAMARA RODRÍGUEZ-RIVERA ${ }^{1,2}$, PATRICIA CUAUTLE-RODRÍGUEZ ${ }^{2,3}$, \\ FERNANDO CASTILLO-NÁJERA ${ }^{4}$ and JUAN ARCADIO MOLINA-GUARNEROS ${ }^{1}$
}

\author{
${ }^{1}$ Department of Pharmacology, Medicine Faculty, Universidad Nacional Autónoma de México, Mexico City 04510; \\ ${ }^{2}$ Posgrado en Ciencias Biológicas; ${ }^{3}$ Research Division, Medicine Faculty, Universidad Nacional Autónoma de México, \\ Mexico City 04510; ${ }^{4}$ Centro de Salud Portales, Mexico City 03660, México
}

Received February 3, 2017; Accepted May 16, 2017

DOI: $10.3892 / b r .2017 .921$

\begin{abstract}
Type 2 diabetes mellitus (T2DM) is one of the most prevalent chronic pathologies in the world. In developing countries, such as Mexico, its prevalence represents an important public health and research issue. Determining factors triggering T2DM are environmental and genetic. While diet, exercise and proper weight control are the first measures recommended to improve the quality of life and life expectancy of patients, pharmacological treatment is usually the next step. Within every population there are variations in interindividual drug response, which may be due to genetic background. Some of the most frequent first line T2DM treatments in developing countries are sulfonylureas (SU), whose targets are ATP-sensitive potassium channels $\left(\mathrm{K}_{\text {ATP }}\right)$. Single nucleotide polymorphisms (SNPs) of the $\mathrm{K}_{\text {ATP }}$ coding genes, potassium voltage-gated channel subfamily J member 11 (KCNJ11) and ATP binding cassette subfamily $\mathrm{C}$ member 8 (ABCC8) have been associated with SU response variability. To date, there is little information regarding the mechanism by which these SNPs work within Mexican populations. The present study describes the distribution of three SNPs [KCNJ11 rs5219 (E23K), ABCC8 rs757110 (S1369A) and rs1799854 (-3C/T)] among Mestizo Mexican (MM) T2DM patients, and compares it with published data on various healthy subjects and T2DM populations. Through this comparison, no difference in
\end{abstract}

Correspondence to: Dr Juan Arcadio Molina-Guarneros, Department of Pharmacology, Medicine Faculty, Universidad Nacional Autónoma de México, 3000 Mexico Avenue, Mexico City 04510, Mexico

E-mail: molina_ja2007@yahoo.com.mx

Abbreviations: MM, Mestizo Mexican; T2DM, type 2 diabetes mellitus; SNP, single nucleotide polymorphism; SU, sulfonylurea; $\mathrm{K}_{\mathrm{ATP}}$, ATP-sensitive potassium channel; ME, metformin

Key words: diabetes, pharmacogenetics, potassium voltage-gated channel subfamily $\mathrm{J}$ member 11 , ATP binding cassette subfamily $\mathrm{C}$ member 8, Mestizo Mexican the $K C N J 11$ rs5219 and ABCC8 rs757110 allelic and genotypic frequencies in $\mathrm{MM}$ were observed compared with the majority of the reported populations of healthy and diabetic individuals among other ethnic groups; except for African and Colombian individuals. By contrast, ABCC8 rs1799854 genomic and allelic frequencies among MM were observed to be significantly different from those reported by the 1000 Genomes Project, and from diabetic patients within other populations reported in the literature, such as the European, Asian and Latin-American individuals $[\mathrm{T}=0.704, \mathrm{G}=0.296$; $\mathrm{CC}=0.506$, $\mathrm{CT}=0.397, \mathrm{TT}=0.097 ; 95 \%$ confidence interval $(\mathrm{CI}) ; \mathrm{P} \leq 0.05]$; except for South Asian and Iberian populations, which may reflect the admixture origins of the present Mexican population. This genetic similarity has not been observed in the other Latin-American groups. To the best of our knowledge, this is the first study of ABCC8 rs757110 and rs1799854 SNP frequencies in any Mexican population and, specifically with diabetic Mexicans. Knowledge of the genetic structure of different populations is key to understanding the interindividual responses to drugs, such as SU and whether genotypic differences affect clinical outcome.

\section{Introduction}

Diabetes is a type of metabolic disease characterized by hyperglycemia resulting from either defective insulin secretion, insulin action or the two (1). The most prevalent type of diabetes is type 2 diabetes mellitus (T2DM), which is one of the leading causes of morbidity globally, as well as the third-highest risk factor for premature mortality (2).

In Mexico, T2DM has led mortality rates since 2005 and today it represents the leading cause of death in the country $(3,4)$ with a prevalence of $11.8 \%(5)$. Costs associated with medical treatment of T2DM are $\sim 450$ million dollars annually (6), while $\sim 75 \%$ of diagnosed patients do not observe adequate glycemic control even with medical assistance. These factors make T2DM a critical concern for the Mexican State's public health and research systems.

While genetic factors causing T2DM have not yet been sufficiently defined, they are currently under extensive study. Numerous T2DM-associated genes present as single nucleotide polymorphisms (SNPs) whose frequencies vary among 
different populations. Genetic variations associated with either pharmacological targets or drug metabolism are of particular interest, as different responses to pharmacological treatments may be explained by the presence of a genetic mutation or the combination of various genotypes (7).

The initial pharmacological treatments for T2DM are oral hypoglycemiants $(\mathrm{OH})$, with sulfonylureas (SU) and metformin (ME) being the two most commonly administered in developing countries. SU are a type of oral $\mathrm{OHs}$, which inhibit ATP-sensitive potassium channels $\left(\mathrm{K}_{\mathrm{ATP}}\right)$, thus inducing glucose-independent insulin release by the $\beta$-pancreatic cells (8). However, not all T2DM patients respond to the anti-diabetic action of SU (primary failure) and those who initially respond adequately may experience a decrease in its efficacy following the years (as variable as 1-2 to 10 or more years) of treatment (secondary failure) $(9,10)$. SUs are frequently combined with $\mathrm{ME}$, a drug which reduces hepatic glucose production and insulin resistance (11). It has been observed that the short-term reduction of glycated hemoglobin A1c (HbA1c) is similar in SU and ME monotherapies (12), and that this drug combination reduces HbA1c more efficiently than SU alone (13). When compared, observations on the adjuvant effects of SU/ME-based treatments are inconclusive; while certain authors have associated hypoglycemic events of different severity and weight increase to SUs, either alone or in combination with ME (14), others have reported no effect on body weight when combining SUs with ME (15). However, due to their low cost and accessibility, SUs (alone or combined with ME) remain the most frequent first-line T2DM treatment in the world, particularly in developing countries, such as Mexico $(16,17)$. The UK Prospective Diabetes Study demonstrated that only $25 \%$ of patients achieved glycemic control of $<7 \%$ in $\mathrm{HbA} 1 \mathrm{c}$ over a nine-year follow-up period of monotherapy on either SU or ME (10).

Of the genetic polymorphisms that have already been reviewed extensively and whose clinical implications have already been analyzed $(18,19)$, there are a number, which appear to be well suited for pharmacogenetic studies. Various SNPs have been reported among $\mathrm{K}_{\mathrm{ATP}}$-channel encoding genes [potassium voltage-gated channel subfamily $\mathrm{J}$ member 11 $(K C N J 11)$ and ATP binding cassette subfamily $\mathrm{C}$ member 8 $(A B C C 8)]$ as the therapeutic target of SU (20). Many of these genes are associated with T2DM predisposition or progression, as well as with SU response variability. A specific SNP frequency may vary between different populations; therefore, it is important to evaluate and compare its distribution among different human populations, in order to better understand whether there is an association between drug response variability, patients' glycemic control and genetic architecture.

In the present study, the frequencies of three pharmacologically important SNPs are described in a Mestizo Mexican (MM) population and, in order to compare these with other reported populations, the distribution of KCNJ11 rs5219 (E23K), ABCC8 rs757110 (S1369A) and rs1799854 (-3C/T) is presented in MM T2DM patients. The aim of the present study is to increase the understanding of the genetic characteristics of specific populations. This may facilitate with elucidating the causes of therapeutic failure and the findings may also be extrapolated and/or compared to other populations in order to improve treatment options and patient management.

\section{Materials and methods}

Patient selection and study design. This study was observational and included 247 T2DM patients recruited from July 2014 to October 2016 from two health centers: 145 from Centro de Salud Portales and 102 T2DM patients from Centro de Salud Mixcoac, both located in Mexico City's Benito Juárez Health Jurisdiction (Mexico). Out of the total adult patient population, 165 were females while 82 were males. Patient eligibility criteria were as follows: Self-proclaimed MM ancestry of at least three generations; age between 18 and 90 years; individuals diagnosed with T2DM according to the American Association of Diabetes criteria (1); individuals taking OHs, the SU glibenclamide alone or combined with $\mathrm{ME}$, for at least 3 months. All participants were enrolled in their health centers after providing written informed consent. Patient clinical history, anthropometrics and biochemical characteristics were obtained from their clinical records (a summary of this data is presented in Table I).

Genotyping. Genomic DNA was obtained by taking $6 \mathrm{ml}$ peripheral blood through arm phlebotomy in glass EDTA-tubes (Vacutainer ${ }^{\circledR}$; BD Biosciences, Franklin Lakes, NJ, USA) from each patient. Patients were fasted at the time of blood sampling. Genomic DNA was isolated from $200 \mu \mathrm{l}$ total blood, using the UltraClean ${ }^{\circledR}$ BloodSpin ${ }^{\circledR}$ DNA Isolation kit (Mo Bio Laboratories, Inc., Carlsbad, CA, USA), and the DNA-extraction protocol was performed according to the manufacturer's instructions. DNA quality was achieved by electrophoresis in Invitrogen 1\% agarose gels (UltraPure ${ }^{\mathrm{TM}}$ Agarose; Thermo Fisher Scientific, Inc., Waltham, MA, USA), at $100 \mathrm{~V}$ over $50 \mathrm{~min}$. DNA concentration was measured by spectrophotometry (Jenway 7305; Cole-Parmer Ltd., Staffordshire, UK). The KCNJ11 rs5219 (E23K), ABCC8 rs757110 (S1369A) and rs1799854 (-3C/T) polymorphisms were determined using $20 \mathrm{ng}$ total genomic DNA per reaction, by allelic discrimination via quantitative polymerase chain reaction (qPCR) using a Vii ${ }^{\mathrm{TM}} 7$ Real-Time PCR system and TaqMan ${ }^{\circledR}$ SNP assays (Applied Biosystems; Thermo Fisher Scientific, Inc. Waltham, MA, USA) using the standard cycling conditions as follows: An initial denaturation stage $95^{\circ} \mathrm{C}$ for $10 \mathrm{~min}, 40$ cycles of denaturation $95^{\circ} \mathrm{C}$ for $15 \mathrm{sec}$, and annealing at $60^{\circ} \mathrm{C}$ for $1 \mathrm{~min}$, and post read stage or final extension at $60^{\circ} \mathrm{C}$ for $30 \mathrm{sec}$.

Statistical analysis. The SNP frequencies of KCNJ11 rs5219, ABCC8 rs757110 and rs1799854 were determined through direct counting, the remaining analyses were performed using SPSS 23.0 for Windows (IBM Corp., Armonk, NY, USA). The SNP frequencies of the patients from both health centers were compared by performing $\chi^{2}$ test of independence. In addition, biochemical and anthropometric data were compared using two-way analysis of variance (ANOVA). The total frequencies for each SNP were compared with those of other populations using the $\chi^{2}$ test of independence. $\mathrm{P}<0.05$ with $95 \%$ CI was considered to indicate a statistically significant difference.

\section{Results}

Mexican-Mestizo sample characteristics. No statistically significant differences were identified after comparing 
Table I. Demographic baseline disease characteristics.

\begin{tabular}{lccc}
\hline Parameter & $\begin{array}{c}\text { Total } \\
(\mathrm{n}=247)\end{array}$ & $\begin{array}{c}\text { Female } \\
(\mathrm{n}=165)\end{array}$ & $\begin{array}{c}\text { Male } \\
(\mathrm{n}=82)\end{array}$ \\
\hline Age (years) & $60.43 \pm 0.75$ & $60.05 \pm 0.91$ & $61.24 \pm 1.34$ \\
Weight $(\mathrm{kg})$ & $70.87 \pm 1.06$ & $69.25 \pm 1.23$ & $74.40 \pm 1.98$ \\
$\begin{array}{l}\text { Body mass } \\
\text { index (kg/m²) }\end{array}$ & $29.51 \pm 0.37$ & $30.26 \pm 0.45$ & $27.89 \pm 0.62$ \\
$\begin{array}{l}\text { Diabetes diagnosis } \\
\text { years) }\end{array}$ & $10.27 \pm 0.61$ & $9.57 \pm 0.64$ & $11.92 \pm 1.34$ \\
$\begin{array}{l}\text { Triglycerides (mg/dl) } \\
\text { Glycated hemoglobin }\end{array}$ & $799.06 \pm 8.02$ & $199.59 \pm 9.44$ & $197.90 \pm 15.24$ \\
$\begin{array}{l}\text { A1c }(\%) \\
\text { Fasting plasma } \\
\text { glucose (mg/dl) }\end{array}$ & $141.86 \pm 4.06$ & $144.55 \pm 5.22$ & $135.76 \pm 5.99$ \\
Cholesterol (mg/dl) & $194.82 \pm 2.71$ & $197.24 \pm 3.45$ & $189.39 \pm 4.12$ \\
\hline
\end{tabular}

Values are presented as means \pm standard error of the mean.

biochemical and anthropometric data from the individuals from the two health centers (data not shown). Within the whole sample, there were approximately twice as many females as there were males (162 females and 83 males); $61.5 \%$ of the patients were overweight $(55.7 \%$ of females and $73.8 \%$ of males); $25 \%$ of the subjects presented with grade I obesity ( $27.9 \%$ in females and $20.0 \%$ in males). The mean period since the first T2DM diagnosis was 10 years, with a mean of $7.55 \pm 0.15 \%$ for HbA1c and $141.86 \pm 4.06 \mathrm{mg} / \mathrm{dl}$ for fasting plasma glucose (FPG). A summary of anthropometrics and biochemical characteristics of our subjects is presented in Table I.

No significant differences were observed in genotypic and allelic frequency distribution between the two health centers (data not shown). The genotyping frequencies of the three SNPs in the whole sample were in Hardy-Weinberg equilibrium (Table II). The obtained allelic and genotypic frequencies were compared with those reported for other non-diabetic populations using data from the 1000 Genomes Project (21) and from literature on T2DM patients; the comparative of each SNP is presented in Tables III-V (22-38). For the present study, studies were included that involved populations of T2DM subjects that were comparable with the current sample.

SNP comparison with other populations. KCNJ11 rs5219 $(\mathrm{E} 23 \mathrm{~K})$ allelic and genotypic frequencies in $\mathrm{MM}$ individuals were not identified to be different between all of the T2DM populations that were compared [predominantly European (EUR) and Asian]. To the best of our knowledge, there were only two other studies from Mexican rs5219 allelic frequencies, which demonstrated no difference compared with the MM population: T2DM Mestizo from Yucatan and T2DM Mayans. In the 1000 Genomes Project populations, MM frequencies were only statistically different from African individuals $(\mathrm{P}=2.17 \mathrm{E}-12$ and $\mathrm{P}=2.31 \mathrm{E}-19$ for allelic and genotypic frequencies, respectively) and admixed American-Colombians
Table II. Genotypic frequencies of the analyzed polymorphisms.

\begin{tabular}{lrrr}
\hline SNP & Frequency & $\%$ & P-value \\
\hline E23K & & & 0.69 \\
GG & 93 & 37.7 & \\
GA & 112 & 45.3 & \\
AA & 42 & 17.0 & \\
Total & 247 & 100.0 & 0.55 \\
-3C/T & & & \\
CC & 125 & 50.6 & \\
CT & 98 & 39.7 & \\
TT & 24 & 9.7 & \\
Total & 247 & 100.0 & \\
S1369A & & & \\
AA & 75 & 30.4 & \\
AC & 131 & 53.0 & \\
CC & 41 & 16.6 & \\
Total & 247 & 100.0 & \\
\hline
\end{tabular}

$\mathrm{P}<3.84$ using the $\chi^{2}$ test for Hardy-Weinberg equilibrium.

from Medellin ( $\mathrm{P}=0.002$ and $\mathrm{P}=7.20 \mathrm{E}-05$ for allelic and genotypic frequencies, respectively; Table III).

MM ABCC8 rs757110 (S1369A) allelic and genotypic frequencies behave similarly to rs5219. The only statistical differences were observed when compared with African individuals $(\mathrm{P}=1.45 \mathrm{E}-13$ and $\mathrm{P}=1.72 \mathrm{E}-23$ for allelic and genotypic frequencies, respectively) and American-Colombians from Medellin $(\mathrm{P}=6.13 \mathrm{E}-04$ and $\mathrm{P}=2.52 \mathrm{E}-06$ for allelic and genotypic frequencies, respectively). Currently, to the best of our knowledge, there are no other studies regarding allelic or genotypic frequencies of this SNP in a Mexican population (Table IV).

ABCC8 rs1799854 (-3C/T) SNP allelic and genotypic frequencies from MM were significantly different from all of the compared T2DM populations (primarily European and Asian). In comparison to non-diabetic populations from the 1000 Genomes Project, MM allelic and genotypic frequencies were significantly different from African individuals, East Asians, the majority of EUR individuals, and other admixed Americans from Colombia, Peru, Puerto Rico and individuals of Mexican ancestry from Los Angeles. Only in Iberic EUR and South Asian individuals did the 1000 Genomes Project report non-significant differences in allelic and genotypic frequencies compared with MM (Table V). Currently, to the best of our knowledge, there are no other studies on the frequencies of these SNPs among Mexican populations of non-diabetic or diabetic individuals.

\section{Discussion}

In the present study, in the MM from Mexico City, rs5219 allelic and genotypic frequencies were not different from the majority of the reported populations of healthy and diabetic individuals among other ethnic groups, except for the African and Colombian subjects; the same observation applies to 
Table III. Potassium voltage-gated channel subfamily J member 11 rs5219 (E23K) allelic and genotypic frequency comparison.

\begin{tabular}{|c|c|c|c|c|c|c|c|c|c|c|c|c|c|c|}
\hline Author (year) & Population & $\mathrm{T}$ & $\mathrm{n}$ & G & $\mathrm{N}$ & $\mathrm{p} ¥$ & $\mathrm{TT}$ & $\mathrm{n}$ & TG & $\mathrm{n}$ & GG & $\mathrm{n}$ & $\mathrm{p} ¥$ & Refs. \\
\hline \multicolumn{15}{|c|}{1000 Genomes Project } \\
\hline \multirow{11}{*}{$\begin{array}{l}\text { Auton et al } \\
(2015)\end{array}$} & MM & 0.603 & 298 & 0.397 & 196 & - & 0.377 & 93 & 0.453 & 112 & 0.17 & 42 & & $(21)$ \\
\hline & AFR & 0.977 & 1291 & 0.023 & 31 & $2.17 \mathrm{E}-12^{\mathrm{a}}$ & 0.956 & 632 & 0.047 & 27 & 0.003 & 2 & $2.31 \mathrm{E}-19^{\mathrm{a}}$ & \\
\hline & EAS & 0.662 & 667 & 0.338 & 341 & 0.387 & 0.429 & 216 & 0.466 & 235 & 0.105 & 53 & 0.386 & \\
\hline & SAS & 0.604 & 591 & 0.396 & 387 & 0.988 & 0.38 & 186 & 0.448 & 219 & 0.172 & 84 & 0.997 & \\
\hline & EUR & 0.647 & 651 & 0.353 & 355 & 0.52 & 0.4 & 201 & 0.495 & 249 & 0.105 & 53 & 0.406 & \\
\hline & EUR IBS & 0.617 & 132 & 0.383 & 82 & 0.839 & 0.374 & 40 & 0.486 & 52 & 0.14 & 15 & 0.815 & \\
\hline & AMR & 0.707 & 491 & 0.293 & 203 & 0.121 & 0.496 & 172 & 0.424 & 147 & 0.081 & 28 & 0.084 & \\
\hline & AMR CLM & 0.803 & 151 & 0.197 & 37 & $0.002^{\mathrm{a}}$ & 0.638 & 60 & 0.33 & 31 & 0.032 & 3 & $7.20 \mathrm{E}-05^{\mathrm{a}}$ & \\
\hline & AMR MXL & 0.594 & 76 & 0.406 & 52 & 0.897 & 0.328 & 21 & 0.531 & 34 & 0.141 & 9 & 0.54 & \\
\hline & AMR PEL & 0.682 & 116 & 0.318 & 54 & 0.243 & 0.435 & 37 & 0.494 & 42 & 0.071 & 6 & 0.092 & \\
\hline & AMR PUR & 0.712 & 148 & 0.288 & 60 & 0.104 & 0.519 & 54 & 0.385 & 40 & 0.096 & 10 & 0.086 & \\
\hline \multicolumn{15}{|l|}{ Type 2 diabetic } \\
\hline $\begin{array}{l}\text { Hernandez- } \\
\text { Escalante } \text { et al } \\
(2014)\end{array}$ & AMR YCN & 0.633 & 164 & 0.367 & 95 & 0.662 & - & - & - & - & - & - & - & (22) \\
\hline $\begin{array}{l}\text { Lara-Riegos et al } \\
\text { (2015) }\end{array}$ & AMR MYN & 0.654 & 75 & 0.346 & 40 & 0.449 & - & - & - & - & - & - & - & (23) \\
\hline $\begin{array}{l}\text { He et al } \\
(2008)\end{array}$ & $\begin{array}{l}\text { EAS } \\
\text { (China) }\end{array}$ & 0.62 & 124 & 0.38 & 76 & 0.805 & 0.35 & 35 & 0.54 & 54 & 0.11 & 11 & 0.34 & (24) \\
\hline $\begin{array}{l}\text { Yokoi et al } \\
(2006)\end{array}$ & $\begin{array}{l}\text { EAS } \\
\text { (Japan) }\end{array}$ & 0.614 & 1954 & 0.386 & 1226 & 0.873 & 0.384 & 610 & 0.462 & 734 & 0.155 & 246 & 0.959 & $(25)$ \\
\hline $\begin{array}{l}\text { Holstein et al } \\
\text { (2009) }\end{array}$ & $\begin{array}{l}\text { EUR } \\
\text { (Germany) }\end{array}$ & 0.604 & 116 & 0.396 & 76 & 0.988 & 0.385 & 37 & 0.437 & 42 & 0.177 & 17 & 0.975 & (27) \\
\hline $\begin{array}{l}\text { Gloyn et al } \\
\text { (2001) }\end{array}$ & EUR (UK) & 0.593 & 427 & 0.407 & 293 & 0.885 & 0.369 & 133 & 0.447 & 161 & 0.183 & 66 & 0.97 & (28) \\
\hline $\begin{array}{l}\text { Sesti et al } \\
(2009)\end{array}$ & $\begin{array}{l}\text { EUR } \\
\text { (Italy) }\end{array}$ & 0.642 & 674 & 0.358 & 376 & 0.569 & 0.385 & 202 & 0.514 & 270 & 0.101 & 53 & 0.338 & (29) \\
\hline $\begin{array}{l}\text { Ragia et al } \\
(2012)\end{array}$ & $\begin{array}{l}\text { EUR } \\
\text { (Grece) }\end{array}$ & 0.668 & 235 & 0.332 & 117 & 0.339 & 0.455 & 80 & 0.426 & 75 & 0.119 & 21 & 0.423 & (30) \\
\hline $\begin{array}{l}\text { Javorsky et al } \\
(2012)\end{array}$ & $\begin{array}{l}\text { EUR } \\
\text { (Slovakia) }\end{array}$ & 0.599 & 121 & 0.401 & 81 & 0.954 & 0.366 & 37 & 0.465 & 47 & 0.168 & 17 & 0.984 & (31) \\
\hline $\begin{array}{l}\text { Klen et al } \\
(2014)\end{array}$ & $\begin{array}{l}\text { EUR } \\
\text { (Slovenia) }\end{array}$ & 0.622 & 194 & 0.378 & 118 & 0.783 & 0.378 & 59 & 0.487 & 76 & 0.135 & 21 & 0.76 & (32) \\
\hline $\begin{array}{l}\text { Nicolac et al } \\
(2009)\end{array}$ & $\begin{array}{l}\text { EUR } \\
\text { (Croatia) }\end{array}$ & 0.607 & 277 & 0.393 & 179 & 0.954 & 0.382 & 87 & 0.452 & 103 & 0.167 & 38 & 0.997 & (33) \\
\hline $\begin{array}{l}\text { Chistiakov et al } \\
\text { (2009) }\end{array}$ & $\begin{array}{l}\text { EUR } \\
\text { (Russia) }\end{array}$ & 0.496 & 128 & 0.504 & 130 & 0.128 & 0.217 & 28 & 0.558 & 72 & 0.225 & 29 & $0.045^{\mathrm{a}}$ & (34) \\
\hline $\begin{array}{l}\text { Sokolova et al } \\
\text { (2015) }\end{array}$ & $\begin{array}{l}\text { WAS } \\
\text { (East Russia) }\end{array}$ & 0.649 & 1926 & 0.351 & 1042 & 0.501 & 0.428 & 635 & 0.442 & 656 & 0.13 & 193 & 0.647 & (35) \\
\hline
\end{tabular}

${ }^{\text {ap }}<0.05$ (95\% confidence interval); $¥ ¥, \mathrm{c}^{2}$ test of independence; MM, type 2 diabetic Mestizo Mexican (1000 Genomes Project third release); AFR, African individuals (1000 Genomes Project third release); EAS, East Asian individuals (1000 Genomes Project third release); SAS, East South Asian individuals (1000 Genomes Project third release); EUR, European individuals (1000 Genomes Project third release); IBS, Iberian population in Spain; AMR, Admixed American; CLM, Colombians from Medellin, Colombia; MXL, Mexican ancestry from Los Angeles, USA; PEL, Peruvians from Lima, Peru; PUR, Puerto Ricans from Puerto Rico (1000 Genomes Project third release); YCN, type 2 diabetic from Mestizo Yucatan; MYN, T2D Mayan.

rs757110 (Tables III and IV). It appears that the distribution of these polymorphisms prevails among the majority of populations, while the ancestral allele is most frequent among African individuals. The results from the Colombian population may reflect the ancestral admixture history of the country, where the African component is widely spread across the Pacific and Caribbean regions (39-41).

In Mexican populations, rs5219 is the only SNP reported for $\mathrm{K}_{\mathrm{ATP}}$-coding genes, exhibiting no differences between the alleles of healthy and T2DM subjects, even when the geographical and ethnic profile of the three Mexican samples were markedly different: The healthy volunteers were Mestizo from the South East (22), the T2DM group had Mayan Amerindian ancestry (23) and our group (MM) was formed by Mestizo individuals, primarily from the central area of Mexico.

To the best of our knowledge, this is the first report of $A B C C 8$ rs757110 and rs1799854 SNPs in Mexican populations, and more specifically, in diabetic Mexican patients. 
Table IV. ATP binding cassette subfamily C member 8 S1369A allelic and genotypic frequency comparison.

\begin{tabular}{|c|c|c|c|c|c|c|c|c|c|c|c|c|c|c|}
\hline Author (year) & Population & $\mathrm{T}$ & $\mathrm{n}$ & G & $\mathrm{n}$ & $\mathrm{p} ¥$ & $\mathrm{TT}$ & $\mathrm{n}$ & TG & $\mathrm{n}$ & GG & $\mathrm{n}$ & $\mathrm{p} ¥$ & Refs. \\
\hline \multicolumn{15}{|c|}{1000 Genomes Project } \\
\hline \multirow{11}{*}{$\begin{array}{l}\text { Auton et al } \\
(2015)\end{array}$} & MM & 0.569 & 281 & 0.431 & 213 & & 0.304 & 75 & 0.53 & 131 & 0.166 & 41 & & (21) \\
\hline & AFR & 0.975 & 1289 & 0.025 & 33 & $1.45 \mathrm{E}-13^{\mathrm{a}}$ & 0.953 & 630 & 0.044 & 29 & 0.003 & 2 & $1.72 \mathrm{E}-23^{\mathrm{a}}$ & \\
\hline & EAS & 0.639 & 644 & 0.361 & 364 & 0.195 & 0.395 & 199 & 0.488 & 246 & 0.117 & 59 & 0.331 & \\
\hline & SAS & 0.585 & 572 & 0.415 & 406 & 0.819 & 0.354 & 173 & 0.462 & 226 & 0.184 & 90 & 0.652 & \\
\hline & EUR & 0.648 & 652 & 0.352 & 354 & 0.252 & 0.404 & 203 & 0.489 & 246 & 0.107 & 54 & 0.238 & \\
\hline & IBS & 0.617 & 132 & 0.383 & 82 & 0.49 & 0.374 & 40 & 0.486 & 52 & 0.14 & 15 & 0.567 & \\
\hline & AMR & 0.693 & 481 & 0.307 & 213 & 0.069 & 0.47 & 163 & 0.447 & 155 & 0.084 & 29 & $0.030^{\mathrm{a}}$ & \\
\hline & CLM & 0.793 & 149 & 0.207 & 39 & $6.13 \mathrm{E}-04^{\mathrm{a}}$ & 0.606 & 57 & 0.372 & 35 & 0.021 & 2 & $2.52 \mathrm{E}-06^{\mathrm{a}}$ & \\
\hline & MXL & 0.586 & 75 & 0.414 & 53 & 0.808 & 0.328 & 21 & 0.516 & 33 & 0.156 & 10 & 0.932 & \\
\hline & PEL & 0.682 & 116 & 0.318 & 54 & 0.098 & 0.435 & 37 & 0.494 & 42 & 0.071 & 6 & 0.041 & \\
\hline & PUR & 0.678 & 141 & 0.322 & 67 & 0.111 & 0.462 & 48 & 0.433 & 45 & 0.106 & 11 & 0.061 & \\
\hline \multicolumn{15}{|c|}{ Type 2 diabetics } \\
\hline $\begin{array}{l}\text { Zhang et al } \\
\text { (2007) }\end{array}$ & $\begin{array}{l}\text { EAS } \\
\text { (China) }\end{array}$ & 0.565 & 130 & 0.435 & 100 & 0.954 & 0.33 & 38 & 0.47 & 54 & 0.2 & 23 & 0.676 & (38) \\
\hline $\begin{array}{l}\text { Yokoi et al } \\
\text { (2006) }\end{array}$ & $\begin{array}{l}\text { EAS } \\
\text { (Japan) }\end{array}$ & 0.592 & 1884 & 0.408 & 1296 & 0.742 & 0.358 & 570 & 0.468 & 744 & 0.174 & 276 & 0.655 & $(25)$ \\
\hline $\begin{array}{l}\text { Klen et al } \\
\text { (2014) }\end{array}$ & $\begin{array}{l}\text { EUR } \\
\text { (Slovenia) }\end{array}$ & 0.619 & 193 & 0.381 & 119 & 0.471 & 0.378 & 59 & 0.481 & 75 & 0.141 & 22 & 0.536 & (32) \\
\hline $\begin{array}{l}\text { Nicolac et al } \\
(2009)\end{array}$ & $\begin{array}{l}\text { EUR } \\
\text { (Croatia) }\end{array}$ & 0.607 & 277 & 0.393 & 179 & 0.585 & 0.395 & 90 & 0.425 & 97 & 0.18 & 41 & 0.301 & (33) \\
\hline $\begin{array}{l}\text { Sokolova et al } \\
\text { (2015) }\end{array}$ & $\begin{array}{l}\text { East Russia } \\
\text { (West Asia) }\end{array}$ & 0.623 & 1763 & 0.377 & 1065 & 0.436 & 0.393 & 556 & 0.46 & 651 & 0.146 & 207 & 0.414 & (35) \\
\hline
\end{tabular}

${ }^{\text {ap }}<0.05$ (95\% confidence interval); $¥ ¥, \mathrm{c}^{2}$ test of independence; CDMX, type 2 diabetics from Mestizo Mexico City (all of the following are 1000 Genomes Project third release): AFR, African; EAS, East Asian; SAS, South Asian; EUR, European; IBS, Iberian population in Spain; AMR, Admixed American; CLM, Colombians from Medellin, Colombia; MXL, Mexican ancestry from Los Angeles, USA; PER, Peruvians from Lima, Peru; PUR, Puerto Ricans from Puerto Rico.

rs757110 allelic and genotypic frequencies behaved similarly to rs5219 SNP, which was to be expected as it is well known that these SNPs form a haplotype. Yet, rs1799854 SNP frequencies seem extremely different to those reported by the 1000 Genomes Project and the literature on various diabetic populations (Table V). A comparison between allelic and genotypic frequencies in the investigated group and those populations reported by the 1000 Genomes Project, demonstrated differences between all but three samples: South Asian, European and Iberic. The Iberic population may have affected the comparison result of the EUR sample, as it was included in the EUR group in the 1000 Genome Project data. This was consistent with the fact that other EUR diabetic populations from different ethnic origins were statistically different when compared with the MM group (UK, Croatia and Poland). These results may reflect the Hispanic admixture dting from Mexico's colonial past; however, it is interesting and unexpected that this was not observed in the other Latin-American populations reported. It was demonstrated by the results of the previous Mexican health and nutrition national survey (ENSANUT 2012) that diabetes diagnosis and first level medical attention have improved considerably in Mexico (5), yet the percentage of treated patients actually maintaining adequate glycemic control remains poor. If this lack of control is genetic, at least partially, the differences observed in Mexican genetic SNP frequencies may significantly contribute to explaining treatment failure. This first screening may facilitate with understanding where focus and investigations are required to establish whether genetic structure and pharmacological failure are associated.

It would be interesting to observe whether a healthy control group of MM individuals from central Mexico behaves the same as diabetic subjects, and to analyze groups of different ethnicity within the country to establish whether those results are consistent with or different from the present study.

The SNPs, rs5219 (E23K) and rs757110 (S1369A) form a haplotype, where K23/A1369 has been identified as a risk genotype $(35,42,43)$. While electrophysiological studies have demonstrated that channels containing the $\mathrm{K}$ allele and K23/A1369 are less sensitive to ATP inhibition $(44,45)$, the SU response of these polymorphic channels appears to be different depending on the drug. For example, it has been shown that K23/A1369 channels are more sensitive to SU gliclazide, yet these same channels are less sensitive to inhibition by SUs, such as tolbutamide and glimepiride, while glibenclamide demonstrated no significant inhibition difference in any haplotype $(45,46)$. In another study, $\mathrm{K}$ allele carriers exhibited significantly higher secondary treatment failure than E allele homozygous (29) treated with SU and ME; however, Dawed et al (19) demonstrated that secondary failure on patients treated with a combination of SU and ME, carrying the K allele polymorphism of rs5219 may be more involved with diabetes progression than with SU response (19).

In Mexico, the most common first level treatment for T2DM combines ME with glibenclamide administration (5). 
Table V. ATP binding cassette subfamily C member 8 -3C/T Allelic and genotypic frequency comparison.

\begin{tabular}{|c|c|c|c|c|c|c|c|c|c|c|c|c|c|c|}
\hline Authors (year) & Population & $\mathrm{C}$ & $\mathrm{n}$ & $\mathrm{T}$ & $\mathrm{n}$ & $\mathrm{p} ¥$ & $\mathrm{CC}$ & $\mathrm{n}$ & $\mathrm{CT}$ & $\mathrm{n}$ & TT & $\mathrm{n}$ & $\mathrm{p} ¥$ & Refs. \\
\hline \multicolumn{15}{|c|}{1000 Genomes Project } \\
\hline \multirow{11}{*}{$\begin{array}{l}\text { Auton et al } \\
(2015)\end{array}$} & MM & 0.704 & 348 & 0.296 & 146 & - & 0.506 & 125 & 0.397 & 98 & 0.097 & 24 & - & $(21)$ \\
\hline & AFR & 0.862 & 1139 & 0.138 & 183 & $0.006^{\mathrm{a}}$ & 0.741 & 490 & 0.241 & 159 & 0.018 & 12 & $7.96 \mathrm{E}-04^{\mathrm{a}}$ & \\
\hline & EAS & 0.449 & 453 & 0.551 & 555 & $2.41 \mathrm{E}-04^{\mathrm{a}}$ & 0.198 & 100 & 0.502 & 253 & 0.3 & 151 & $2.20 \mathrm{E}-06^{\mathrm{a}}$ & \\
\hline & SAS & 0.681 & 666 & 0.319 & 312 & 0.724 & 0.481 & 235 & 0.401 & 196 & 0.119 & 58 & 0.865 & \\
\hline & EUR & 0.58 & 583 & 0.42 & 423 & 0.067 & 0.33 & 166 & 0.499 & 251 & 0.171 & 86 & $0.031^{\mathrm{a}}$ & \\
\hline & EUR IBS & 0.612 & 131 & 0.388 & 83 & 0.17 & 0.393 & 42 & 0.439 & 47 & 0.168 & 18 & 0.169 & \\
\hline & AMR & 0.464 & 322 & 0.536 & 372 & $5.35 \mathrm{E}-04^{\mathrm{a}}$ & 0.225 & 78 & 0.478 & 166 & 0.297 & 103 & $1.30 \mathrm{E}-05^{\mathrm{a}}$ & \\
\hline & AMR CLM & 0.516 & 97 & 0.484 & 91 & $0.006^{\mathrm{a}}$ & 0.266 & 25 & 0.5 & 47 & 0.234 & 22 & $0.001^{\mathrm{a}}$ & \\
\hline & AMR MXL & 0.422 & 54 & 0.578 & 74 & $5.10 \mathrm{E}-05^{\mathrm{a}}$ & 0.172 & 11 & 0.5 & 32 & 0.328 & 21 & $1.35 \mathrm{E}-07^{\mathrm{a}}$ & \\
\hline & AMR PEL & 0.312 & 53 & 0.688 & 117 & $1.91 \mathrm{E}-08^{\mathrm{a}}$ & 0.071 & 6 & 0.482 & 41 & 0.447 & 38 & $3.15 \mathrm{E}-14^{\mathrm{a}}$ & \\
\hline & AMR PUR & 0.567 & 118 & 0.433 & 90 & $0.044^{\mathrm{a}}$ & 0.346 & 36 & 0.442 & 46 & 0.212 & 22 & $0.022^{\mathrm{a}}$ & \\
\hline \multicolumn{15}{|l|}{ Type 2 diabetics } \\
\hline $\begin{array}{l}\text { He } \text { et al } \\
(2008)\end{array}$ & $\begin{array}{l}\text { EAS } \\
\text { (China) }\end{array}$ & 0.41 & 82 & 0.59 & 118 & $2.50 \mathrm{E}-05^{\mathrm{a}}$ & 0.14 & 14 & 0.54 & 54 & 0.32 & 32 & $1.03 \mathrm{E}-08^{\mathrm{a}}$ & (24) \\
\hline $\begin{array}{l}\text { Yokoi et al } \\
\text { (2006) }\end{array}$ & $\begin{array}{l}\text { EAS } \\
\text { (Japan) }\end{array}$ & 0.474 & 1507 & 0.526 & 1673 & $8.91 \mathrm{E}-04^{\mathrm{a}}$ & 0.233 & 371 & 0.481 & 765 & 0.286 & 454 & $2.90 \mathrm{E}-05^{\mathrm{a}}$ & (25) \\
\hline $\begin{array}{l}\text { Matharoo et al } \\
\text { (2013) }\end{array}$ & $\begin{array}{l}\text { SAS } \\
\text { (India) }\end{array}$ & 0.568 & 227 & 0.433 & 173 & $0.044^{\mathrm{a}}$ & 0.405 & 81 & 0.325 & 65 & 0.27 & 54 & $0.006^{\mathrm{a}}$ & (36) \\
\hline $\begin{array}{l}\text { Gloyn et al } \\
\text { (2001) }\end{array}$ & $\begin{array}{l}\text { EUR } \\
\text { (UK) }\end{array}$ & 0.464 & 412 & 0.536 & 476 & $5.35 \mathrm{E}-04^{\mathrm{a}}$ & 0.191 & 85 & 0.545 & 242 & 0.264 & 117 & $3.50 \mathrm{E}-06^{\mathrm{a}}$ & (28) \\
\hline $\begin{array}{l}\text { Nicolac et al } \\
\text { (2009) }\end{array}$ & $\begin{array}{l}\text { EUR } \\
\text { (Croatia) }\end{array}$ & 0.489 & 223 & 0.511 & 233 & $0.002^{\mathrm{a}}$ & 0.197 & 45 & 0.583 & 133 & 0.219 & 50 & $1.30 \mathrm{E}-05^{\mathrm{a}}$ & (33) \\
\hline $\begin{array}{l}\text { Dworacka et al } \\
\text { (2007) }\end{array}$ & $\begin{array}{l}\text { EUR } \\
\text { (Poland) }\end{array}$ & 0.45 & 36 & 0.55 & 44 & $2.54 \mathrm{E}-04^{\mathrm{a}}$ & 0.25 & 10 & 0.4 & 16 & 0.35 & 14 & $6.00 \mathrm{E}-06^{\mathrm{a}}$ & (37) \\
\hline
\end{tabular}

${ }^{a} \mathrm{P}<0.05$ (95\% confidence interval); $\mathrm{p} ¥, \mathrm{c}^{2}$ test of independence; CDMX, type 2 diabetics from Mestizo Mexico City (all of the following are 1000 Genomes Project third release): AFR, African; EAS, East Asian; SAS, South Asian; EUR, European; IBS, Iberian population in Spain; AMR, Admixed American; CLM, Colombians from Medellin, Colombia; MXL, Mexican ancestry from Los Angeles, USA; PER, Peruvians from Lima, Peru; PUR, Puerto Ricans from Puerto Rico.

In this first analysis, whose objective was mainly SNP frequency description, the authors included patients receiving glibenclamide or ME either as a mono- or combined therapy, as the SNP distribution is not affected by treatment. In future studies, the aim will be to investigate clinical implications of using ME-only treated patients as a control group to distinguish the ME effect.

The $A B C C 8$ rs1799854 polymorphism has been associated with a predisposition for diabetes $(25,47,48)$. In terms of pharmacogenetics, certain studies have found that the TT genotype may be associated with an increase in HbAlc and triglyceride levels in SU-treated diabetics $(33,49)$, and deemed partially determinant of hyperglycemia-cardiovascular risk factor in rs1799854 heterozygotes (37). However, other authors report no significant associations when analyzing FPG and BMI $(28,50)$. Even when results in the case of this SNP are contradictory, the difference in the allelic and genotypic frequencies observed in our sample in comparison with the majority of reported cases, indicates a considerable requirement to evaluate their implications in diabetes progression and drug response in the MM population.

The SNP frequencies of rs5219 and rs757110 polymorphisms appear to be well conserved among the majority of populations, including Mexicans, there is not yet a clear association between them and the pharmacological effects.
The present results may contribute to future studies to clarify whether there is a real association.

The aim of the present study was to describe the genetic architecture of three pharmacogenetically important SNPs of ABCC8 and KCNJ11 within an MM population. To the best of our knowledge, this study is the first to report allelic and genotypic frequencies of ABCC8 rs757110 and rs1799854 SNPs in an MM population. Diabetes is a major concern in Mexico, and current pharmacological treatment is considered insufficient, as shown by the latest national health survey. Therefore, understanding the characteristics of our population is a priority for elucidating a viable hypothesis to improve our knowledge of this complex pathology. It is known that interindividual responses to SU are affected by clinical factors, such as baseline glucose levels, disease duration, $\beta$-cell function and insulin resistance levels (51). However, multiple gene interaction may explain the marginal impact of each individual SNP, indicating, the necessity to construct an interaction model.

\section{Acknowledgements}

The present study was conducted as part of the Universidad Nacional Autónoma de México (National Autonomous University of Mexico-UNAM) Biological Sciences PhD postgraduate academic program fulfillment, and it was supported 
by the Programa de Apoyo a Proyectos de Investigación e Innovación Tecnológica (Support Program for Research and Technological Innovation Projects-PAPIIT) as the IN218216 Dirección General de Apoyo a Personal Académico (General Directorate for Academic Personnel Support-DGAPA)-UNAM project. The authors would like to thank María de los Ángeles Granados-Silvestre for her technical assistance and training in the use of the qPCR equipment and sample processing; Professor Marta Menjivar-Hiraeta for the access granted to her facility and equipment to perform qPCR experiments. To Dr Isaac González Romero (Centro de Salud Portales), Dr Mario Alberto Tinoco Centeno and Mr. José Antonio Rojas (Centro de Salud Mixcoac) for providing his technical expertise for sample collection.

\section{References}

1. American Diabetes Association: Diagnosis and classification of diabetes mellitus. Diabetes Care 37 (Suppl 1): S81-S90, 2014.

2. World Health Organization: Global health risks: Mortality and burden of disease attributable to selected major risks. Geneva, 2009.

3. Hernandez AM: PROYECTO de Modificación a la Norma Oficial Mexicana NOM-015-SSA2-1994, Para la prevención, tratamiento y control de la diabetes; para quedar como Norma Oficial Mexicana PROY-NOM-015-SSA2-2007, Para la prevención, tratamiento y control de la diabetes mellitus. Diario Oficial de la Federación, Mexico. http://legismex.mty.itesm. mx/normas/ssa2/ssa2015-09pm.pdf. Accessed Oct 20, 2009.

4. Navarro Robles AG, astañeda Vargas JC, Alam Mittilo B, et al: Agenda Estadística 2010. Journal 171: 2010, 2011.

5. Jiménez-Corona A, Aguilar-Salinas CA, Rojas-Martínez R and Hernández-Ávila M: Type 2 diabetes and frecuency of prevention and control measures. Salud Publica Mex 55 (Suppl 2): S137-S143, 2013 (In Spanish).

6. Rodríguez Bolaños RdeL, Reynales Shigematsu LM, Jiménez Ruíz JA, Juárez Márquezy SA and Hernández Ávila M: Direct costs of medical care for patients with type 2 diabetes mellitus in Mexico micro-costing analysis. Rev Panam Salud Publica 28: 412-420, 2010 (In Spanish).

7. Singh S, Usman K and Banerjee M: Pharmacogenetic studies update in type 2 diabetes mellitus. World J Diabetes 7 : $302-315,2016$.

8. Glamočlija U and Jevrić-Čaušević A: Genetic polymorphisms in diabetes: influence on therapy with oral antidiabetics. Acta Pharm 60: 387-406, 2010.

9. Kota SK, Meher LK, Jammula S, Kota SK and Modi KD Genetics of type 2 diabetes mellitus and other specific types of diabetes; its role in treatment modalities. Diabetes Metab Syndr 6: 54-58, 2012.

10. UK Prospective Diabetes Study (UKPDS) Group: Intensive blood-glucose control with sulphonylureas or insulin compared with conventional treatment and risk of complications in patients with type 2 diabetes (UKPDS 33). Lancet 352: 837-853, 1998.

11. Kirpichnikov D, McFarlane SI and Sowers JR: Metformin: An update. Ann Intern Med 137: 25-33, 2002.

12. Bennett WL, Maruthur NM, Singh S, Segal JB, Wilson LM, Chatterjee R, Marinopoulos SS, Puhan MA, Ranasinghe P, Block L, et al: Comparative effectiveness and safety of medications for type 2 diabetes: An update including new drugs and 2-drug combinations. Ann Intern Med 154: 602-613, 2011.

13. Maruthur NM, Tseng E, Hutfless S, Wilson LM, Suarez-Cuervo C, Berger Z, Chu Y, Iyoha E, Segal JB and Bolen S: Diabetes medications as monotherapy or metformin-based combination therapy for type 2 diabetes: A systematic review and meta-analysis. Ann Intern Med 164: 740-751, 2016.

14. Klein-Schwartz W, Stassinos GL and Isbister GK: Treatment of sulfonylurea and insulin overdose. Br J Clin Pharmacol 81: 496-504, 2016

15. Lim PC and Chong CP: What's next after metformin? focus on sulphonylurea: Add-on or combination therapy. Pharm Pract (Granada) 13: 606, 2015.

16. Altagracia-Martínez M,Kravzov J, Moreno Md R, et al: Diabetes Mellitus Tipo2: Ventas de los Hipoglucemiantes Orales y Costos de los Tratamientos Farmacológicos en México. Rev Mex Cienc Farm 38: 23-33, 2007
17. Díaz de León-Castañeda C, Altagracia-Martínez M, Kravzov-Jinich J, Cárdenas-Elizalde MdelR, Moreno-Bonett C and Martínez-Núñez JM: Cost-effectiveness study of oral hypoglycemic agents in the treatment of outpatients with type 2 diabetes attending a public primary care clinic in Mexico City. Clinicoecon Outcomes Res 4: 57-65, 2012.

18. Loganadan NK, Huri HZ, Vethakkan SR and Hussein Z: Genetic markers predicting sulphonylurea treatment outcomes in type 2 diabetes patients: Current evidence and challenges for clinical implementation. Pharmacogenomics J 16: 209-219, 2016.

19. Dawed AY, Zhou K and Pearson ER: Pharmacogenetics in type 2 diabetes: Influence on response to oral hypoglycemic agents. Pharmgenomics Pers Med 9: 17-29, 2016.

20. Gloyn AL and McCarthy MI: The genetics of type 2 diabetes. Best Pract Res Clin Endocrinol Metab 15: 293-308, 2001.

21. Auton A, Brooks LD, Durbin RM, Garrison EP, Kang HM, Korbel JO, Marchini JL, McCarthy S, McVean GA and Abecasis GR; 1000 Genomes Project Consortium: A global reference for human genetic variation. Nature 526: 68-74, 2015.

22. Hernandez-Escalante VM, Nava-Gonzalez EJ, Voruganti VS, Kent JW, Haack K, Laviada-Molina HA, Molina-Segui F, Gallegos-Cabriales EC, Lopez-Alvarenga JC, Cole SA, et al: Replication of obesity and diabetes-related SNP associations in individuals from Yucatán, México. Front Genet 5: 380, 2014.

23. Lara-Riegos JC, Ortiz-López MG, Peña-Espinoza BI, Montúfar-Robles I, Peña-Rico MA, Sánchez-Pozos K, Granados-Silvestre MA and Menjivar M: Diabetes susceptibility in Mayas: Evidence for the involvement of polymorphisms in HHEX, HNF4 $\alpha$, KCNJ11, PPAR $\gamma$, CDKN2A/2B, SLC30A8, CDC123/CAMK1D, TCF7L2, ABCA1 and SLC16A11 genes. Gene 565: 68-75, 2015.

24. He YY, Zhang R, Shao XY, Hu C, Wang CR, Lu JX, Bao YQ, Jia WP and Xiang KS: Association of KCNJ11 and ABCC8 genetic polymorphisms with response to repaglinide in Chinese diabetic patients. Acta Pharmacol Sin 29: 983-989, 2008.

25. Yokoi N, Kanamori M, Horikawa Y, Takeda J, Sanke T, Furuta H, Nanjo K, Mori H, Kasuga M, Hara K, et al: Association studies of variants in the genes involved in pancreatic beta-cell function in type 2 diabetes in Japanese subjects. Diabetes 55: 2379-2386, 2006.

26. Rastegari A, Rabbani M, Sadeghi HM, Imani EF, Hasanzadeh A and Moazen F: Association of KCNJ11 (E23K) gene polymorphism with susceptibility to type 2 diabetes in Iranian patients. Adv Biomed Res 4: 1, 2015.

27. Holstein A, Hahn M, Stumvoll M and Kovacs P: The E23K variant of KCNJ11 and the risk for severe sulfonylurea-induced hypoglycemia in patients with type 2 diabetes. Horm Metab Res 41: 387-390, 2009.

28. Gloyn AL, Hashim Y, Ashcroft SJ, Ashfield R, Wiltshire S and Turner RC; UK Prospective Diabetes Study (UKPDS 53): Association studies of variants in promoter and coding regions of beta-cell ATP-sensitive K-channel genes SUR1 and Kir6.2 with type 2 diabetes mellitus (UKPDS 53). Diabet Med 18: 206-212, 2001

29. Sesti G, Laratta E, Cardellini M, Andreozzi F, Del Guerra S, Irace C, Gnasso A, Grupillo M, Lauro R, Hribal ML, et al: The E23K variant of KCNJ11 encoding the pancreatic beta-cell adenosine 5'-triphosphate-sensitive potassium channel subunit Kir6.2 is associated with an increased risk of secondary failure to sulfonylurea in patients with type 2 diabetes. J Clin Endocrinol Metab 91: 2334-2339, 2006.

30. Ragia G, Tavridou A, Petridis I and Manolopoulos VG: Association of KCNJ11 E23K gene polymorphism with hypoglycemia in sulfonylurea-treated type 2 diabetic patients. Diabetes Res Clin Pract 98: 119-124, 2012

31. Javorsky M, Klimcakova L, Schroner Z, Zidzik J, Babjakova E, Fabianova M, Kozarova M, Tkacova R, Salagovic J and Tkac I: KCNJ11 gene E23K variant and therapeutic response to sulfonylureas. Eur J Intern Med 23: 245-249, 2012.

32. Klen J, Dolžan V and Janež A: CYP2C 9 , KCNJ11 and ABCC8 polymorphisms and the response to sulphonylurea treatment in type 2 diabetes patients. Eur J Clin Pharmacol 70: 421-428, 2014.

33. Nikolac N, Simundic AM, Katalinic D, Topic E, Cipak A and Zjacic Rotkvic V: Metabolic control in type 2 diabetes is associated with sulfonylurea receptor-1 (SUR-1) but not with KCNJ11 polymorphisms. Arch Med Res 40: 387-392, 2009.

34. Chistiakov DA, Potapov VA, Khodirev DC, Shamkhalova MS, Shestakova MV and Nosikov VV: Genetic variations in the pancreatic ATP-sensitive potassium channel, beta-cell dysfunction, and susceptibility to type 2 diabetes. Acta Diabetol 46: 43-49, 2009. 
35. Sokolova EA, Bondar IA, Shabelnikova OY, Pyankova OV and Filipenko ML: Replication of KCNJ11 (p.E23K) and ABCC8 (p.S1369A) association in Russian diabetes mellitus 2 type cohort and meta-analysis. PLoS One 10: e0124662, 2015.

36. Matharoo K, Arora P and Bhanwer AJ: Association of adiponectin (AdipoQ) and sulphonylurea receptor (ABCC8) gene polymorphisms with type 2 diabetes in North Indian population of Punjab. Gene 527: 228-234, 2013.

37. Dworacka M, Winiarska H and Jagodziński PP: Impact of the sulfonylurea receptor 1 (SUR1) exon 16-3c/t polymorphism on acute hyperglycaemia in type 2 diabetic patients. Diabetes Res Clin Pract 77: 258-262, 2007.

38. Zhang H, Liu X, Kuang H, Yi R and Xing H: Association of sulfonylurea receptor 1 genotype with therapeutic response to gliclazide in type 2 diabetes. Diabetes Res Clin Pract 77: 58-61, 2007.

39. Rojas W, Parra MV, Campo O, Caro MA, Lopera JG, Arias W, Duque C, Naranjo A, García J, Vergara C, et al: Genetic make up and structure of Colombian populations by means of uniparental and biparental DNA markers. Am J Phys Anthropol 143: 13-20, 2010.

40. Ossa H, Aquino J, Pereira R, Ibarra A, Ossa RH, Pérez LA, Granda JD, Lattig MC, Groot H, Fagundes de Carvalho E, et al: Outlining the ancestry landscape of Colombian admixed populations. PLoS One 11: e0164414, 2016.

41. Homburger JR, Moreno-Estrada A, Gignoux CR, Nelson D, Sanchez E, Ortiz-Tello P, Pons-Estel BA, Acevedo-Vasquez E, Miranda P, Langefeld CD, et al: Genomic insights into the ancestry and demographic history of South America. PLoS Genet 11: e1005602, 2015.

42. Florez JC, Burtt N, de Bakker PI, Almgren P, Tuomi T, Holmkvist J, Gaudet D, Hudson TJ, Schaffner SF, Daly MJ, et al: Haplotype structure and genotype-phenotype correlations of the sulfonylurea receptor and the islet ATP-sensitive potassium channel gene region. Diabetes 53: 1360-1368, 2004.

43. Gloyn AL, Weedon MN, Owen KR, Turner MJ, Knight BA, Hitman G, Walker M, Levy JC, Sampson M, Halford S, et al: Large-scale association studies of variants in genes encoding the pancreatic beta-cell KATP channel subunits Kir6.2 (KCNJ11) and SUR1 (ABCC8) confirm that the KCNJ11 E23K variant is associated with type 2 diabetes. Diabetes 52: 568-572, 2003.
44. Schwanstecher C, Meyer U and Schwanstecher M: K(IR)6.2 polymorphism predisposes to type 2 diabetes by inducing overactivity of pancreatic beta-cell ATP-sensitive $\mathrm{K}(+)$ channels. Diabetes 51: 875-879, 2002

45. Hamming KS, Soliman D, Matemisz LC, Niazi O, Lang Y, Gloyn AL and Light PE: Coexpression of the type 2 diabetes susceptibility gene variants KCNJ11 E23K and ABCC8 S1369A alter the ATP and sulfonylurea sensitivities of the ATP-sensitive K(+) channel. Diabetes 58: 2419-2424, 2009.

46. Lang VY, Fatehi M and Light PE: Pharmacogenomic analysis of ATP-sensitive potassium channels coexpressing the common type 2 diabetes risk variants E23K and S1369A. Pharmacogenet Genomics 22: 206-214, 2012.

47. Inoue H, Ferrer J, Welling CM, Elbein SC, Hoffman M, Mayorga R, Warren-Perry M, Zhang Y, Millns H, Turner R, et al: Sequence variants in the sulfonylurea receptor (SUR) gene are associated with NIDDM in Caucasians. Diabetes 45: 825-831, 1996

48. Hart LM, de Knijff P, Dekker JM, Stolk RP, Nijpels G, van der Does FE, Ruige JB, Grobbee DE, Heine RJ and Maassen JA: Variants in the sulphonylurea receptor gene: Association of the exon 16-3t variant with type II diabetes mellitus in Dutch Caucasians. Diabetologia 42: 617-620, 1999.

49. Meirhaeghe A, Helbecque N, Cottel D, Arveiler D, Ruidavets JB, Haas B, Ferrières J, Tauber JP, Bingham A and Amouyel P: Impact of sulfonylurea receptor 1 genetic variability on non-insulin-dependent diabetes mellitus prevalence and treatment: A population study. Am J Med Genet 101: 4-8, 2001.

50. Zychma MJ, Gumprecht J, Strojek K, Grzeszczak W, Moczulski D, Trautsolt W and Karasek D: Sulfonylurea receptor gene 16-3 polymorphism - association with sulfonylurea or insulin treatment in type 2 diabetic subjects. Med Sci Monit 8: CR512-CR515, 2002.

51. Dawed AY, Donnelly L, Tavendale R, Carr F, Leese G, Palmer CN, Pearson ER and Zhou K: CYP2C8 and SLCO1B1 variants and therapeutic response to thiazolidinediones in patients with type 2 diabetes. Diabetes Care 39: 1902-1908, 2016. 